\title{
A (TRANS) FORMAÇÃO \\ HUMANA NA PERSPECTIVA \\ FOUCAULTIANA: INTERPELAÇÓES \\ À EDUCAÇÁO ESCOLAR E À \\ DOCÊNCIA NA ATUALIDADE
}

Pedro Angelo Pagni ${ }^{1}$

\section{Resumo}

O tema da formação humana vem sendo objeto de uma longa discussão no âmbito dos estudos em Filosofia da Educaçáo. $\mathrm{O}$ presente artigo procura abordar esse tema a partir do pensamento de Michel Foucault e, ao privilegiar essa perspectiva teórica, apresentar uma de suas faces mais radicais, objetivando vistas a discutir as possibilidades da restituição do sentido formativo da educação escolar e da docência na atualidade. Para isso, recorremos à obra e aos últimos cursos desse filósofo, particularmente, ao momento em que articula sua ontologia crítica à estética da existência, ao seu retorno aos gregos para problematizar no presente a filosofia e a pedagogia e aos conceitos em torno dos quais sustenta o que chama de pragmática de si. Dessa forma, procuramos contribuir para o atual debate sobre o assunto, no campo da Filosofia da Educação, e para uma reflexão acerca das possibilidades do sentido (trans)formativo da educação escolar, no presente.

Palavras-chave: Formação humana; Michel Foucault; Arte de viver; Psicagogia; Educação escolar.

1 Pedro Angelo Pagni é professor adjunto do Departamento de Administração e Supervisão Escolar e do programa de Pós-graduação em Educação da Faculdade de Filosofia e Ciências da UNESP, Campus de Marília.

E-mail: pagni@terra.com.br 
The theme of human formation has been object of a long discussion within the framework of the studies in the philosophy of education. This article seeks to address this theme from the thought of Michel Foucault and, by favoring this theoretical perspective, to present one of his faces more radical, aiming to discuss the possibilities of the refund of the formation of school education and sense of teaching today. For that, we turn to the work and the last courses of this philosopher, particularly at the moment in which articulates its critical ontology aesthetics of existence, to his return to the Greeks to discuss in this philosophy and pedagogy and the concepts around which maintains what it calls himself pragmatic. In this way, we seek to contribute to the current debate on the subject in the field of philosophy of education, and a reflection on the possibilities of meaning (trans) formation of school education, in the present.

Keywords: Human formation; Michel Foucault; Art of living; Psicagogía; School education. 


\section{A (TRANS)FORMAÇÃO \\ HUMANA NA PERSPECTIVA \\ FOUCAULTIANA: INTERPELAÇÓES \\ À EDUCAÇÁO ESCOLAR E À DOCÊNCIA NA ATUALIDADE}

A formação humana tem sido um tema corrente nos estudos em Filosofia da Educação em nosso país. O que tem potencializado a sua discussão mais recente, além das preocupações presentes, são as possibilidades de pensá-lo a partir de diversas perspectivas da Filosofia Contemporânea. Ao meu julgamento, nesse debate, nenhuma perspectiva filosófica parece ter sido mais radical ao pensá-lo do que aquela que, em busca da transformação de si, postula um modo de fazer da própria existência uma obra de arte.

Essa perspectiva inaugurada por Nietzsche teve, na contemporaneidade, o seu delineamento, dentre outros, nas primeiras obras de Gilles Deleuze e, principalmente, nas últimas obras de Michel Foucault. Diferentemente de outros filósofos contemporâneos, o problema desses dois últimos filósofos ou o modo como problematizam o empobrecimento da experiência formativa e a destituição da vida no cenário biopolítico atual, é distinto, inclusive, entre eles. Em virtude dos limites deste artigo, não me aterei a explicitar essas diferenças, tampouco em aprofundar o pensamento de cada um desses filósofos, mas privilegiar o pensamento de Foucault de modo a propor um recorte de seus últimos livros e cursos e uma interpretação sobre uma perspectiva que almejaria uma reversão do olhar sobre a formaçáo humana e que poderia interpelar no presente as práticas compreendidas pela educação escolar. Este é objetivo específico deste artigo que, em um plano mais amplo, procura contribuir para elucidar o modo como essa perspectiva teórica aborda esse tema e para 
o debate produzido no campo da Filosofia da Educação, nos últimos anos, no Brasil.

Para tais propósitos, no primeiro momento deste artigo, analiso o modo como esse filósofo francês concebe a relação entre a sua ontologia crítica e a estética da existência, de modo a evidenciar em que pressupostos sustentam a sua concepçáo de vida como obra de arte. Em seguida, ao analisar tal concepção formativa a partir das noçóes de subjetivação e experimentação, reconstituo brevemente a importância que esse filósofo concede à filosofia como arte de viver e a psicagogía como contrapontos às filosofias e pedagogias modernas, respectivamente, problematizando as formas como aquela disciplina e essa arte constituiu no presente. Discuto algumas interpelaçóes à educação escolar e à atividade docente, por fim, que poderiam advir a partir da interpretação da parresía e, sobretudo, da pragmática de si na experiência da antiguidade greco-romana desenvolvidas por Foucault, levantando algumas questóes para que sejam pensadas pelos educadores na atualidade e contribuam para certo deslocamento do debate sobre a temática da formação no campo da Filosofia da Educação.

\section{DA ONTOLOGIA CRÍTICA À ESTÉTICA DA EXISTÊNCIA: A VIDA COMO OBRA DE ARTE}

Ao retomar o ensaio de Kant sobre o iluminismo, Foucault (2000, p. 174) procura fazê-lo em defasagem ao projeto elaborado na Crítica da Razão Pura, argumentando que a Aufklärung evocaria um apelo à coragem, uma atitude, necessária para se sair da autoinculpável menoridade. Se, no projeto crítico kantiano, o apelo à coragem é modulado pela obediência, pelo respeito à autoridade instituída e à proposição de outra arte de governo, superior, porque regida por um ideal verdadeiro e por uma moral transcendental, nesse ensaio, comenta ele, a sua indicação é a de que a Aufklärung se aproximaria de uma atitude crítica em relação 
então existente, no século XVIII, Kant teria se colocado em questáo, como seu elemento e ator de um processo histórico, como sujeito, enfim, que problematiza o presente, interrogando o seu tempo e a si mesmo sobre o seu próprio esclarecimento, redefinindo esse movimento acerca do objeto da reflexão do filósofo e da crítica filosófica. Para ele, esse problema não teria sido esquecido por Kant, a ponto de ser retomado em $O$ Conflito das Faculdades (1798), em que se pergunta: “O que é revolução?”. Se o texto sobre a Aufklärung teria lhe permitido inaugurar um "[...] discurso filosófico da modernidade e sobre a modernidade" e interpelar o presente (com questóes como: Qual é esta minha atualidade? Qual é o sentido desta atualidade? E o que faço quando falo desta atualidade?), o segundo texto teria introduzido a revoluçáo como um acontecimento que possuiria um valor de signo (rememorativo, demonstrativo e prognóstico), na medida em que suscita em seu entorno o entusiasmo. Esse entusiasmo é signo de uma "disposição moral da humanidade", que se manifesta como direito de escolha a uma constituição política e como esperança que esta última evite a guerra de todos contra todos. Enquanto signo, a revolução seria o (entusiasmo) que finaliza e que dá continuidade à Aufklärung. E, enquanto problemas do presente, ambos não poderiam ser esquecidos na modernidade, tanto que, desde Kant, foram constantemente repostos na história do pensamento que o sucedeu, inclusive em seu trabalho filosófico.

Por mais que advogue encontrar em Kant um precursor do discurso filosófico da ou sobre a modernidade, poder-se-ia dizer, Foucault (1984) não postula uma suposta superioridade dada pelo sublime, mas, no máximo, que tal sentimento é parte de uma prova ou fortalecimento moral frente a esse acontecimento e, mais precisamente, este se manifesta como signo (rememorativo, demonstrativo e prognóstico) que necessariamente invoca uma experiência ou uma experimentação. Nesse caso, o que promoveria a necessária relação entre a estética e a ética não seriam os juízos do

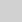

cencia na atualidade 
gosto, mas o acontecimento e a sua remissão a uma filosofia moral que extrapola a repartição entre o subjetivo e objetivo, estabelecida para justificar os juízos reflexivos e determinantes, tampouco seria a pressuposição de um sentimento vivido em virtude do conflito das faculdades, no entanto, talvez, um sentimento comum, experimentado diversamente, como o entusiasmo, capaz de mobilizar certa atitude crítica e eticidade diante da vida, produzindo efeitos no mundo. Mais próxima de um ethos, isto é, como uma atitude diante da vida sobre a qual se esculpem os modos de existência, em tal eticidade o sujeito singular experimenta náo propriamente um conflito das faculdades que pode gerar subjetivamente um sentimento do sublime, mas as forças mesmas da vida, a fortuna que lhe é reservada pelo mundo e, com isso, as incertezas que deve enfrentar cotidianamente, como se vivesse em uma existência trágica, para aludir aos gregos. Nesse sentido, é a própria existência que se tornaria objeto de uma obra de arte e a vida que a compreende, o seu produto. De acordo com Vilela:

A apresentação da existência como uma obra de arte supõe a afirmação da estética como uma forma de vida, ou seja, os valores estéticos passam a constituir-se como a forma, a configuração e a transformação possível da vida. O que está em jogo na perspectivação da existência como uma obra de arte não é a procura nostálgica da autenticidade do ser humano - o ser próprio do homem -, nem o encontro da verdade de si mesmo como uma pura entidade, mas a realizaçáo de um trabalho sobre si mesmo que leva o sujeito a inventar-se. A ética assenta, precisamente, no trabalho que um indivíduo realiza sobre si mesmo, a partir de um conjunto de práticas através das quais se delineiam as suas regras de comportamento, a possibilidade de modificar-se e de transformar seu modo de ser, isto é, de fazer da vida de cada um uma obra de arte. (2010, p. 358 - grifos no 
Neste ponto se vê ecoar, na melodia de Foucault, a de Nietzsche e uma tradição mais antiga da história da filosofia. Ao retomar a gênese moderna dessa outra relação entre estética e ética, entretanto, parece radicalizar o pensamento nietzschiano, ao buscar na filosofia dos estoicos e, antes deles, na origem da filosofia grega, com forte apoio na obra de Pierre Hadot (2002), os exercícios espirituais que prometeram a ascese necessária ao acesso à verdade e o seu regime mais ético que epistemológico, o qual conduz o sujeito que para tal deve ter a formaçáo moral e estar à altura dos acontecimentos.

Para Foucault (2004b), os acontecimentos seriam os responsáveis por esse dobrar-se e habitar as superfícies próprias do estoicismo e de toda uma tradiçấo filosófica em que a abertura ao seu acolhimento e a preparação para ser-lhe digno, eticamente, implicavam um longo trabalho de preparação, ainda que fosse para o impreparável e o imponderável, exigindo uma série de exercícios espirituais e de ascese, denominados filosofia. Estar à altura do acontecimento, quando atravessasse a vida e fosse enfrentado pelo filósofo, seria estar aberto a uma fortuna que, embora jamais fosse conhecida, podendo ser algo terrível ou inebriante àquele que o vive, não importaria em seu sentido trágico ou cômico para o ser singular, mas ao sentido imanente e que emana de racionalidades de um ser do cosmos ou a sua ontologia.

Bastante diferente da clássica, essa ontologia não tem essência, é relacional, estabelecendo-se na relação com a coisa mesma, com o outro e com outrem, com as forças que lhe dão expressão e forma, às quais o ator se dobra, tendo um poder relativo sobre o conhecê-las, podendo apenas ocuparse delas para que náo ponham fim a sua própria vida e em desgraça perante o mundo. A ascese em relação à verdade $\mathrm{e}$ à espiritualidade, próprias da filosofia, auxiliariam a viver a vida segundo essa arte e colocam esta última em seu centro. Antes que uma experiência pensada que pulsa a vida, é esta que impulsa o pensar, sendo a experiência ou a experienciaçáo o que dá forma ao ator e a sua existência, expondo-o ao cencia na atualidade 
mundo e fazendo com que conviva com uma extensa multiplicidade de estilos e de modos de viver. Dessa forma, diversamente do pensamento nietzschiano, que vê na ascese e na espiritualidade uma renúncia à vida, Foucault (2004b) vê nelas uma preparação para o impreparável, vendo nele um fortalecimento moral para suportar os acontecimentos que lhes advêm e na atitude de pensá-los em seu sentido imanente, para potencializar a vida e resistir às forças da existência que tentam extirpá-la ou, simplesmente, apaziguá-la. Restaria saber, no entanto, se se poderia pensar dessa tradiçáo filosófica o acontecimento, a necessidade de preparação pedagógica para acolhê-lo e resguardar o seu sentido ético para a arte de viver se apoiando, na atualidade, numa ontologia semelhante àquela que encontra a sua origem no mundo grego e romano.

A partir dessa perspectiva, parece ser possível problematizar o ideal moderno de formação humana não somente em sua gênese, como também mostrar que, desde então, nasce privilegiando certas tradições da antiguidade grega e romana da Paideia, dando determinados contornos subjetivos e metafísicos a ela, que desprezam outras que a promovem como uma arte de viver e como bem próxima ao modo de existência filosófica, no sentido de uma escolha ética e política.

Não se trata de recuperar nostalgicamente, com isso, a formação antiga do homem grego e romano como forma de vida e como exercício filosófico sobre si mesmo como melhor que o moderno, porque verdadeiro ou mais adequado aos parâmetros da escola e da cultura criadas na modernidade. Ao contrário, parece tratar-se de apresentar como uma alternativa ao que foi completamente abandonado, em virtude de a modernidade presumir certos critérios de verdade, ideias de sujeito e posiçóes em relação ao poder, que desprezam as formas preponderantes como estiveram associados ao ethos, ao devir e à vida, na Antiguidade Clássica e Romana, até chegar ao Renascimento. Nesse sentido, por meio de uma arte da existência seria produtivo, na medida em 
que pode interpelar o destino que foi dado a ela, no presente, e colocá-lo à altura dos desafios contemporâneos, sobretudo, como uma forma de resistência política à formalização do existente e à instrumentalização da cultura, presumindo a assunção de uma atitude ética diante da vida que, concomitantemente, pressupóe certa transformação de si.

É desse ponto de vista que Foucault aborda as práticas de si como meio para se alçar a liberdade, retomando a cultura grega e toda a tradição que entende esta última como "[...] condição ontológica da ética” que, por sua vez, é a "[...] forma refletida da liberdade" (2004a, p. 267). Contudo, para ele, tal condição não seria algum pressuposto a priori, mas se materializaria em uma série de práticas que implicariam o cuidado de si, porque o exercício das práticas de si deveria ser considerado como a busca por práticas de liberdade, quer dizer, práticas que possam ser escolhas éticas no sentido da potencialização da vida e do aprimoramento da existência. Tais práticas seriam consideradas por ele como constituidoras de modos de existência, contrapondose à imobilidade das relaçóes de poder e à sedimentaçáo dos estados de dominação, podendo se encontrar aí certa resistência a estes últimos, por meio do ensaio de outras relaçôes de poder, que resultem na transformação de si e na ampliação da liberdade. Para que isso ocorra, é necessário que os sujeitos participantes de tais relaçóes e estados se ocupem de si mesmos, como um imperativo ontológico e ético imanente, fazendo-os voltarem os seus olhares e os seus pensamentos sobre as verdades e valores morais assimilados em sua existência, a fim de que possam escolher os seus melhores guias e aprender a cuidar dos outros. Assim, não é pelo fato de aprender a cuidar dos outros que esses sujeitos estabeleceriam as suas ligaçóes com a ética, mas é justamente porque eles cuidariam de um si, que lhes é anterior ontologicamente, e que se impóe como um imperativo com base em certa tradiçáo do pensamento e da cultura da Antiguidade.

Ao reconstruir genealogicamente essa tradição, Foucault (2004b) problematiza toda a historiografia da filosofia que interpretou o "conhece-te a ti mesmo" (gnôthi seautón)
A (TRANS) formação

humana na perspectiva

foucaultiana:

interpelações à

docência na atualidad
Educ. foco, Juiz de Fora, 23 v. 20 , n. 2 , p. $15-44$, 
socrático como preponderante sobre o cuidado de si (epiméleia heautôे), para assentar, na consciência de si, as relaçôes entre o sujeito e a verdade, nos termos em que ela foi concebida desde a modernidade. Para Foucault (2004b), o cuidado de si já estaria presente na cultura espartana e emerge nos diálogos platônicos Alcibiades e Apologia, particularmente nos discursos e interpelaçóes de Sócrates. No primeiro diálogo, Sócrates interpela Alcibíades, fazendo com que este último, proveniente de uma família nobre e ávido por assumir o governo da cidade, se ocupe de si mesmo, percebendo que, não obstante o seu desejo e a sua proveniência social, ainda não está em condiçôes para governar os outros, visto que apresenta um déficit pedagógico e erótico em sua formação, ignorância em relação ao objeto de seu projeto político e, enfim, incapacidade em governar a si próprio. Movimento semelhante Sócrates faz, no segundo diálogo, ao interpelar aqueles que o acusam de corromper a juventude ateniense, que resultou em sua morte, pois os incita a ocuparem-se de si sob o argumento de que havia recebido essa tarefa dos deuses e o que fez foi apenas acomodar essa missão divina a um modo de existência que construiu e viveu, ao longo de sua vida - que podemos chamar de filosofia. Em seu desenvolvimento subsequente, em resumo, o cuidado de si se configurou como, na acepção de Foucault: (1) uma atitude geral para consigo, para com os outros e para com o mundo; (2) certa forma de olhar que se desloca de fora para si mesmo, o que acarreta maneiras de atenção "[...] ao que se pensa e ao que passa no pensamento" (2004b, p. 14) e em espécies de práticas, próximas aos exercícios e à meditação; (3) ações exercidas de si para consigo, por meio das quais “[...] nos modificamos, nos purificamos, nos transformamos e nos configuramos" (2004b, p. 15). Em consequência, desde a sua gênese, o cuidado se configurou como uma atitude ética, um modo de atenção e um conjunto de práticas exercidas sobre si mesmo, no sentido de sua própria transformação, sem deixar que o sujeito se fixe em uma fôrma preconcebida e em um eu idêntico a esse si mesmo. 
É a partir dessa política de verdade e do que denomina ontologia do presente que Foucault (1984), assim, retoma o tema do cuidado de si (ephiméleia heautồ), tentando ser consequente em relaçáo ao que entende por atitude crítica, enunciando seu compromisso com as práticas de liberdade e com uma vida vivida de acordo com uma estética da existência. Graças àquela atitude, seria possível buscar modos de existências cada vez mais livres nas relaçóes com as diversas dimensóes e múltiplas artes de governo, resistindo a certas formas de governamentalizaçáo. De acordo com Foucault (2000), a crítica estaria associada a uma constante atitude de não querer ser governado de determinada forma, nas relaçôes estabelecidas pelo sujeito com outro, nas e entre as artes de governo, bem como a uma busca por táticas e estratégias que permitissem modos de existências cada vez mais livres, nos jogos de força compreendidos por essas relaçóes, possibilitando processos de subjetivação nessa direção.

\section{SUBJETIVAÇÁO E A EXPERIMENTAÇÁO: A VIDA COMO OBRA DE ARTE}

Foucault caracteriza a subjetivação como "[...] o processo pelo qual se obtém a constituição de um sujeito, mais precisamente, de uma subjetividade, que evidentemente não passa de uma das possibilidades dadas de organização da consciência de si" (2004d, p. 262). Esse processo ocorre pela, na e com a experiência, visto que compreende esta última como o processo de racionalização que culmina na formação dos sujeitos. Nesse sentido, a subjetivação não se confunde com a pessoa, muito menos com o sujeito, no sentido em que foram concebidos na modernidade. Ao contrário, salienta Deleuze,

[...] é uma individuação particular ou coletiva que caracteriza um acontecimento [...]. É um modo intensivo e não um sujeito pessoal. É uma dimensão específica sem a qual não se poderia ultrapassar o saber nem resistir ao poder. Foucault analisará$$
\text { (n) }
$$

\section{.}

\section{.}


os modos de existência gregos, cristãos, como eles entram em certos saberes, como eles se comprometem com o poder. Mas, neles mesmos, eles são de outra natureza. [...] o que interessa a Foucault não é um retorno aos gregos: mas nós hoje: [...] será que temos maneiras de nos constituirmos como "si", e, como diria Nietzsche, maneiras suficientemente "artistas", para além do saber e do poder? Será que somos capazes disso, já que de certa maneira é a vida e a morte que aí estão em jogo? (2000, p. 123-124).

Dessa forma e com tais interpelações, os processos de subjetivação seriam o material, o fim e o meio sobre o qual se dá a formação enquanto uma arte da existência, que permite viver a vida como uma obra em vistas a transformar o próprio sujeito que a vive e, concomitantemente, o mundo no qual essa vida acontece. Em busca de uma (trans)formação mais adequada à sua existência e de uma ação cada vez mais capaz de exprimi-la no mundo, esse sujeito faria de sua própria subjetividade e de sua construção objeto de seu pensar. Tanto aquela formação quanto essa expressividade consistiriam em uma ligação da estética com a existência e com a sua exposição ao mundo, respectivamente, com o intuito de trazer-lhe as singularidades e as particularidades dos processos de subjetivação, em sua relação com as vicissitudes e os acontecimentos que emanam da vida e que lhe servem tanto de material para pensar quanto de força moral necessária a esse pensamento. São essa subjetividade e essa força que o constituem, ainda que fluidamente, que se encontrariam em todas as esferas da vida e do mundo, podendo ser objetos de seu pensar. No entanto, dado que parte dessa força que o constitui é inconsciente e parte se sedimenta na memória, o fato de se tornarem objetos desse pensar não significa a sua plena consciência ou elaboração intelectual, persistindo como um resto e como um elemento profundo que permanece ativo, vivo, instigando o pensamento a se re-pensar e, em tal ato, potencializando com a vida nua que aí reside o próprio ser desse sujeito ético e de 
seu devir. Assim, haveria nessa potencialização produzida com essa experiência pulsante do pensar uma atitude e uma virtude geral que precede o pensamento e que resiste irrefletidamente ao que não abarca, nem exprime essa experimentação, até que se converta em ato de pensar, isto é, um ato que se produz com as forças e a vontade emanadas da vida e diretamente associado aos modos de sua expressão refletida na existência de sua habitação no mundo, enfim, com um ethos, nos termos anteriormente apresentados.

É justamente esse ethos que parece estar alheio à educação moral pretendida ou, mesmo, à educação do gosto, anteriormente analisadas, dando o que pensar aos sujeitos dessas práticas, principalmente no que se refere ao como e ao onde estaria presente em sua ação e em sua formação, em qual seria o seu campo efetivo de experimentação no presente, com a expectativa de promover a transformação de si mesmos e, por decorrência, do mundo em que os seus resultados emergem.

Diferentemente de buscar a pensar essa transformação mediante os conceitos de subjetivo e objetivo, Foucault parece preferir o conceito de subjetivação para designá-la e, de certo modo, para mostrar que se caracteriza por uma experiência não apenas interior, como Martin Jay (2009) atribui a Bataille, mas provocada por um jogo de forças em que o interior e o exterior intercedem mutuamente. Em síntese, essa alternativa excluiria qualquer possibilidade de processar uma repartição entre o racional e o irracional, nos termos em que modernamente se faz. Ao contrário, significa admitir que, como advogam alguns filósofos antigos, estoicos e cínicos, há uma racionalidade inapreensível pela racionalidade humana e que não permite ao indivíduo conduzir completamente a sua vida como ele bem deseja ou delibera conscientemente, já que tal deliberação subjetiva está sujeita a essa racionalidade outra, às vicissitudes do que se vive e ao acontecimento que lhe acomete. Não teria sentido, dessa forma, acusar de irracionalista essa posição foucaultiana acerca da arte de viver, como a interpretou Hermann (2008). Ao contrário, essa acepção
Educ. foco, Juiz de Fora, 
parece compreender outra racionalidade, não abarcada pela racionalidade subjetiva dos modernos, tampouco por aqueles que almejam a continuidade do projeto da modernidade, evidenciando os limites desta e a arrogância de que a razáo humana apreenderia totalmente a realidade. Assim, viver a vida como obra de arte não significa apenas moldá-la segundo os traços deliberados do artista, como também se dobrar às forças da matéria, às asperezas e rugosidades de sua superfície e daquilo que lhe escapa ao que está sendo moldado, notando aí um limite e esperando que daí emerja algo novo e outros modos de existência.

É justamente aquilo que escapa à estagnação em tal processo e que produz uma experiência do fora (FOUCAULT, 2004c) que provoca a estranheza e a diferença no que o sujeito tem como idêntico a si mesmo, que o faz se inquietar e se ocupar de si próprio, transformando-se. Foucault argumenta que "[...] é a experiência, que é a racionalização de um processo ele mesmo provisório, que redunda em um sujeito, ou melhor, em sujeitos" (2004d, p. 262). Esses sujeitos que, dessa maneira, se formam, re-formam e transformam a si mesmos, produzindo, nesses processos de subjetivação, novos modos de existência e estilos de vida, que, por sua vez, se confrontam com os já existentes e, por vezes, os transformam, transformando o próprio mundo.

Não obstante a expectativa política compreendida por certa interpelação e resistência aos modos de existência que não são mais suportados ou admitidos para guiar a vida individual e coletiva, nos termos expostos, vislumbra-se nessa perspectiva de viver a vida como obra de arte um profundo sentido ético. Embora nos dias de hoje a recomendação de ocuparse consigo mesmo seja interpretada como certo "egoísmo" e "volta sobre si", nos termos indicados por alguns críticos, durante séculos ela significou, ao contrário, de acordo com Foucault, "[...] um princípio positivo matricial relativamente a morais extremamente rigorosas" (2004b, p. 17). Aliás, esse princípio teria sido readaptado pelos códigos e pelas regras do 
cristianismo e da modernidade, para que se constituíssem em morais não egoístas, de obrigação para com os outros, gerando complexos paradoxos e concorrendo para que ocupar-se consigo fosse desprestigiado como constituinte de uma ética ${ }^{2}$.

No âmbito desse tendente desprestígio, para Foucault (2004b, p. 18), restaria à filosofia ser uma forma de pensamento que se interroga não mais sobre o que é verdadeiro ou falso, mas sobre o que torna possível o conhecimento verdadeiro ou falso, possibilitando ao sujeito ter acesso à verdade, conforme os seus limites e as suas possibilidades, porque a espiritualidade da qual a filosofia era parte constituinte ficou desfigurada e sucumbida a esta última, na modernidade. Com isso, a espiritualidade, que compreendia um conjunto de buscas, práticas e experiências que constituem para o sujeito o preço a pagar pela verdade, passou a ser reduzida a um ato do conhecimento que náo mais exige desse mesmo sujeito a sua modificação, transformaçáo, deslocamento para ter direito ao acesso à verdade. Se a espiritualidade póe em jogo o ser mesmo de sujeito, um trabalho de si para consigo para ascender à verdade, retomá-la no presente contra esse modo de restrição a um ato de conhecimento no qual se converteu a filosofia significa confrontá-la com a sua sombra do passado e perguntar sobre o seu sentido, na atualidade.

Desse ponto de vista, o cuidado de si não apenas reverte à forma preponderante de interpretação sobre a Filosofia Antiga, como também coloca em xeque a função da filosofia como um ato de pensar destituído de uma atitude ética e política,

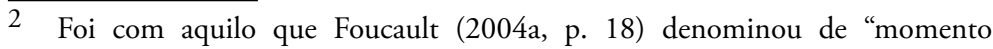
cartesiano" que o cuidado de si foi praticamente esquecido para a requalificação filosófica do "conhece-te a ti mesmo", ao estabelecer como a primeira certeza, necessária ao procedimento filosófico, a evidência de uma consciência entendida como conhecimento de si e, ao fundá-la numa prova ontológica da existência, concebe o sujeito como aquele que tem acesso à verdade. Assim, essa requalificaçáo do "conhece-te a ti mesmo" e desqualificaçáo do cuidado de si, por meio desse procedimento, passa a se constituir como fundante para a filosofia moderna, enquanto a espiritualidade da qual provinha passa a ser desprestigiada.

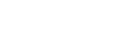


ao recuperá-la como exercício de espiritualidade, como modo de vida e como arte de viver. Tal retomada consiste não em desconsiderar a importância que a filosofia adquiriu como ato de pensar em busca da verdade, mas em entender que essa é apenas uma de suas faces, e não necessariamente a mais importante. Analogamente, podemos dizer algo semelhante quanto à pedagogia, na medida em que, enquanto uma arte de condução das almas, se dissociou em seu desenvolvimento não apenas de uma relação com a verdade, como uma atitude ética e política nos termos da filosofia, mas também, e principalmente, do processo de transformação do ser em que consistiu a psicagogía.

$\mathrm{Na}$ acepção foucaultiana a pedagogia consiste, como diz Castro, na "transmissão de uma verdade que tem por função dotar o sujeito de aptidóes, capacidades e saberes." (2004, p. 258) Por psicagogía, segundo o mesmo autor, Foucault entende "a transmissão de uma verdade que tem por função a modificação do modo de ser do sujeito, e não simplesmente dotá-lo das capacidades que não possui." (CASTRO, 2004, p. 258) Para Foucault, na Antiguidade, a psicagogía estaria muito próxima da pedagogia como arte da condução das almas e de transmissão da verdade, enquanto ambas dependem de uma relação específica entre mestre e discípulo, na qual aquele conduz a alma deste, e são "[...] experimentadas como Paidéia" (2004b, p. 493-494). Com o advento do cristianismo, porém, ocorrem algumas mutaçóes bastante significativas em relação a esses termos, pois, a quem denominam de mestre não é simplesmente um outro humano, tampouco a formação da alma ocorre pela via da condução desse outro e é propagada por meio do discurso enunciado por ele, mas é dado pelo divino, pela revelação e pela confissão, respectivamente.

Nesse desenvolvimento das noçôes de pedagogia e psicagogía, a primeira prevalece sobre a segunda, constituindose como uma arte de transmissão da verdade que forma as aptidóes, capacidades e saberes em um sujeito que náo os possui ou não os tem desenvolvidos por intermédio de 
outrem, que, em tese, deteria a verdade revelada, graças a já ter plenamente formadas aquelas mesmas aptidóes, capacidades e saberes. Ao desvincular-se da pedagogia, dessa forma, a psicagogía se converte num único modo de dizer a verdade, que faria o ser mesmo se modificar, a confissão, com toda a sua particularidade. Assim, com o cristianismo, instaura-se um modo de espiritualidade em que, sublinha Foucault,

[...] é o sujeito do discurso guiado que deve estar presente no interior do discurso verdadeiro como objeto de seu próprio discurso verdadeiro. No discurso daquele que é guiado, o sujeito da enunciaçáo deve ser o referente do enunciado: é a definição de confissão. $\mathrm{Na}$ filosofia greco-romana, ao contrário, quem deve estar presente no discurso verdadeiro é aquele que dirige. E deve estar presente náo sob a forma da referência do enunciado [...]; está presente em uma coincidência entre o sujeito da enunciação e o sujeito de seu próprio enunciado. (2004b, p. 495).

Foi, precisamente, essa coincidência que se perdeu, quando a pedagogia se autonomizou e prevaleceu sobre a psicagogía, no cristianismo, até o completo esquecimento desta última, na modernidade. $\mathrm{O}$ mesmo se pode dizer sobre a relação que a psicagogía estabelecia com um estilo e um modo filosófico de vida e de dizer veraz, já que a pedagogia começa a se fundar em um discurso de verdade proveniente da filosofia como um saber superior e um metadiscurso universal a partir do cristianismo, independente da coincidência com aquele sujeito que o enuncia e os seus modos de ser. Ao retomar, assim, a psicagogía como outra forma de relação com a verdade e, poderíamos dizer, com esse modo de vida denominado filosófico, o filósofo francês, por um lado, problematiza tanto a Pedagogia quanto a Filosofia, na atualidade, mediante a confrontação e o estranhamento gerado com essa reconstituição genealógica desses campos da ação e do saber; por outro, parece indicar a possibilidade da produção de algo novo nessa

cência na atualidade 
diferenciação entre o passado e o presente. Algo que se distinga da formação das aptidóes, das capacidades e saberes, com base na transmissão da verdade pressuposta pela Pedagogia e do modo de relaçáo com a verdade como conhecimento suposto pela Filosofia, para conduzir à transformação do ser do próprio pedagogo e do filósofo ou do pedagogo-filósofo, dos processos de subjetivação produzidos em suas práticas e dos modos de existir que lhes deveriam habitar, para que, ao transformar-se, concorram para a transformaçáo do outro e do mundo.

Nessa reversão das tarefas compreendidas pela filosofia, o ato de pensar e de conhecer é táo importante quanto os exercícios de meditação e outras formas de ascese, dentre outros, que constituem a arte de viver. $\mathrm{O}$ mesmo se pode dizer quanto à pedagogia, que, ao ser tensionada com esse modo de transformação do ser em que consiste a psicagogía, possibilite que a verdade transmitida aos alunos por essa arte seja igualmente importante aos exercícios de meditação, de escuta e de atenção desenvolvidos pelo educador em sua própria ação, assim como a perscrutação nela do que de acontecimental propicia a sua própria transformação. Em decorrência, o mais importante é que essas práticas resultem na transformação de seus agentes, daqueles que escolheram a filosofia como uma atitude diante da vida e como um modo de dizer a verdade ou procuraram na ação formativa um meio de transformar-se, de aprender, na relação com o outro, a enfrentar as vicissitudes dessa mesma vida e assumir a responsabilidade pelo mundo, cultivando a si próprio.

Nessa outra tradição que privilegia a arte filosófica de viver e faz preponderar a psicagogía, a filosofia e a pedagogia se concebem como um conjunto de práticas produzidas por e produtoras de estilos de existência, necessitando para tal da assunção de certa atitude ética diante da vida e de um compromisso com a pólis, por parte de seus agentes que, náo obstante a sua indispensável formação, também precisam estar atentos e dispostos à sua própria transformação. 
$\mathrm{Na}$ Antiguidade Clássica até o Cristianismo, para conduzir as próprias almas e a dos outros, filósofos e pedagogos encontravam, na prática de uma série de exercícios de ascese, certa preparaçáo para o inusitado e para os acontecimentos que atravessam a vida, irrompem no mundo e estariam presentes nas relaçóes que estabelecem com seus discípulos e alunos. De acordo com Foucault, tal askesis se constitui no processo progressivo pelo qual o sujeito exerce um "domínio sobre si mesmo, obtido não através da renúncia à realidade, mas da aquisição e da assimilação da verdade", tendo como meta "o acesso à realidade deste mundo" (Foucault, 2008, p. 74). Nas palavras do filósofo francês, a palavra grega que define essa ascensão à verdade dessa forma é paraskeuazo ("estar preparado") que consiste em "um conjunto de práticas as quais alguém pode adquirir, assimilar e transformar a verdade em um princípio permanente da ação", convertendo a alethéia em ethos e produzindo "um processo para um grau maior de subjetividade" (2008, p. 74).

Essa verdade como "princípio imanente da ação" parece aprofundar a busca da verdade pleiteada pela ontologia do presente e pela atitude crítica que a preside, como uma virtude geral, e não como um fundamento epistemológico no qual o discurso se legitimaria. Por conseguinte, essa mesma virtude parece presidir tanto o que a filosofia como modo de vida ou como estética da existência presume, quanto o que uma pedagogia que se permita compreender por intermédio de uma psicagogía, instando os filósofos e pedagogos não a um retorno ao passado, mas à criaçáo de algo novo.

Conforme enfatiza Foucault (2004a; 2004d), em algumas entrevistas, o retorno à moral e aos modos de vida gregos não visa a relembrar nostalgicamente o passado ou, simplesmente, fazer com que recordemos o que foi esquecido no presente, como uma estratégia de sua problematização. Ao contrário, argumenta ele:

Nada é mais estranho para mim do que a ideia de que a filosofia se desviou em um 
dado momento e esqueceu alguma coisa e que existe algum lugar de sua história um princípio, um fundamento que precisa que seria preciso redescobrir. [...] O que, entretanto, não significa que o contato com esta ou aquela filosofia não possa produzir alguma coisa, mas entáo seria preciso enfatizar que essa coisa é nova. (FOUCAULT, 2004c, p. 280).

A retomada da tradição filosófica e pedagógica, inaugurada por Sócrates, desenvolvida pelos estoicos e pelos cínicos, assim, reporia a vida e a diferença geradora dessa coisa nova no centro do discurso filosófico atual, confrontando este último com o seu passado e com um conjunto de práticas que preparam os sujeitos para serem dignos dos acontecimentos que irrompem da vida e de suas vicissitudes - como sugeriu Deleuze (2000), ao interpretar o estoicismo -, bem como para encarnarem a militância necessária frente aos acontecimentos da história - como Foucault (2009) interpreta a tradição cínica, em sua relação com os movimentos revolucionários do século XIX e de certos movimentos artísticos do século XX.

Ainda que essa última perspectiva teórica postule esse olhar sobre a filosofia como uma arte de viver e a psicagogía como um modo de transmissáo da verdade em que o sujeito se transforma, assim como outro modo de conceber a formação humana, ao fazer da vida uma obra de arte, tais práticas filosófica e pedagógica compreendem igualmente certas artes e tecnologias. Para tal perspectiva, porém, essas práticas seriam ordenadas pelas tecnologias de produçáo, pelo sistema de signos ou pelo poder, mas por um trabalho de si sobre si, em que a busca da inquietação e do cuidado pode levar a um bem governar a si próprio para, quem sabe, cuidar do cuidado do e do governo do outro. É nesse movimento antiassujeitamento e pró-subjetivação de si que Foucault desenvolve que podemos encontrar, no estranhamento suscitado pela arte do viver e pela arte do transmitir a verdade experienciada em que compreende a psicagogía, a criaçáo de 
novos modos de resistência e de subjetivação por meio da filosofia e da pedagogia, no presente. Nele também podemos encontrar certa reversão do ideal moderno de formação e a proposta de uma alternativa que poderia nos auxiliar a criar, se não outra concepção formativa ou de autoformação, ao menos fazer com que nos ocupemos de nossa própria transformação, mesmo que seja na relação com o outro compreendida pela ação formativa que exercemos, como educadores.

\section{INTERPELAÇÓES DA PARRESÍA E DA PRAGMÁTICA DE SI À EDUCAÇÃO ESCOLAR}

Embora possamos buscar em outros filósofos contemporâneos uma alternativa a esse ideal moderno de formaçáo na modernidade, procuramos encontrar no pensamento de Michel Foucault essa possibilidade, particularmente, em sua retomada de uma tradição do pensamento greco-romano abandonada na modernidade e que pode interpelar, no presente, a filosofia e a pedagogia. Isso porque entende que essa outra tradiçáo propóe uma relação diferente com a verdade, nos termos encontrados no conceito greco-romano de parresía, além das formas como esta seria produzida pela filosofia e transmitida pela pedagogia, indicando uma pragmática que contempla uma dramática de si, deveras abandonada no presente, como alternativa ao esquecimento da transformação do ser pela pragmática da linguagem na qual se apoiam a formas de produção e de transmissão dos saberes, incluindo, as práticas adotadas no ensino. Sáo essas alternativas quanto ao discurso de verdade e à pragmática que são os objetos privilegiados nesta última parte do artigo.

É com o intuito de indicar outras relaçôes entre o saberpoder, o sujeito e a verdade que Foucault retoma a noçáo de parresía como um modo de dizer veraz, originalmente elaborado pelos filósofos da antiguidade e posteriormente desenvolvido pelos estoicos, epicuristas e cínicos. Em síntese, a parresía é um modo de falar a verdade, que contrasta com (n) 
a retórica e com um modo de dizê-la em que o sujeito que a enuncia pode dissocia-la daquilo que é enquanto ser; é uma maneira de falar franco que faz com esse sujeito se abra ao risco de dizer essa verdade e se vincule ala por dizê-la a partir do que viveu. De acordo com Foucault: "A parresía é a livre coragem pela qual você se vincula a si mesmo no ato de dizer a verdade. $\mathrm{Ou}$, ainda, a parresía é a ética do dizer-a-verdade, em seu ato arriscado e livre" (2010, p. 64).

Esse modo de relação com a verdade não se dispóe a enunciar, discursivamente, um conhecimento construído por argumentos estruturados logicamente e assentados em uma epistemologia, que garantiria a sua transmissão aos demais. Não se assenta, igualmente, na retórica, ou seja, no uso desses argumentos para convencer um determinado público, graças ao sentido apelativo desse discurso e, ao mesmo tempo, ao clamor pelo assentimento de seus destinatários. Nem mesmo teria como único recurso à dialética, para fazer com que destinador e destinatário encontrem no conflito entre as suas proposiçóes uma verdade resultante de uma síntese superior - porque apoiada em um método e em uma epistemologia que, em tese, representariam uma visão privilegiada no que concerne às existentes. Ao invés disso, a verdade parresiasta seria expressão de um falar franco que acarreta, por um lado, a exposiçáo daquele que a enuncia, como uma espécie de sujeito que acolhe o acontecimento, fazendo desse processo um trabalho constante de sua autotransformação, experienciando-o e, nos limites de suas possibilidades, dizendo-o; por outro, coloca esse mesmo discurso e o seu sujeito em risco, provocando os seus interlocutores, antes de os acomodarem e os deixarem apaziguados. Não se trata também de uma mera confissão mediante a qual se expia a culpa do sujeito do discurso, tomado como seu próprio referente, mas consiste em um dizer veraz em que coincide o discurso enunciado com a verdade vivida pelo sujeito que o enuncia e que, para tal, experimenta em si mesmo uma modificação de seu próprio ser. Assim, esse modo 
como modo de vida e como a psicagogía, contrastando tanto com a concepçáo de verdade preponderantemente buscada pela filosofia quanto com a de sua transmissão postulada pela pedagogia.

Por sua vez, a transformação de si almejada tanto pela arte de viver quanto pela psicagogía não dispensa uma relação com o outro nem uma pragmática. $\mathrm{Na}$ relação com os outros, a linguagem ou o discurso e sua pragmática ou circulação aparecem como elementos importantes. Assim como entende necessário recorrer ao conhecimento de si sobre o primado do cuidado e às diversas tecnologias sob a tecnologia de si, Foucault não deixa de insistir que só se dá a autotransformação do sujeito pressuposta por essas práticas mediante o seu trabalho de dizer o que se passa, o que lhe acontece e aquilo que essa experiência inquieta, na relação com outro e com a mediação da linguagem, do discurso e de sua enunciação. Contudo, Foucault (2010), a pragmática da linguagem que envolve essa relação com o outro não poderia ser aquela que atualmente se concebe como tal e que busca apenas modificar o sentido do discurso, em conformidade com os contextos comunicacionais, porque ela se encontra sob a égide de um dizer veraz, assentada no pressuposto da cognição, da representação e da transmissão, o que lhe possibilita pensar e produzir como diferenciação entre o um e o outro nela compreendidos, assim como transformação de si.

Para Foucault, a "análise da pragmática do discurso é a análise dos elementos e dos mecanismos pelos quais a situação na qual se encontra o enunciador vai modificar o que pode ser o valor ou o sentido do discurso" (2010, p. 65). Na parresía, continua ele,

O enunciado, o ato e enunciação vão, ao mesmo tempo, afetar de uma maneira ou de outra o modo de ser do sujeito e fazer pura e simplesmente - $|. .$.$| -, que aquele que aquele$ que disse a coisa a tenha dito efetivamente, por um ato mais ou menos explícito, ao fato de tê-la dito. Essa retroaçáo, que faz com 
que o acontecimento do enunciado afete o modo de ser do sujeito ou que, ao produzir o acontecimento do enunciado, o sujeito modifique ou afirme, ou em todo caso determine e precise, qual é o seu modo de ser na medida em que fala, pois bem, é isso, a meu ver, que caracteriza um outro tipo de fatos de discurso totalmente distintos dos da pragmática. E o que poderíamos chamar vamos dizer - |...| - de "dramática" do discurso é a análise desses fatos do discurso que mostra como o acontecimento da enunciação pode afetar o ser do enunciador. (...) A análise da parresía é a análise dessa dramática do discurso verdadeiro que revela o contrato do sujeito falante consigo mesmo no ato do dizer-a-verdade (FOUCAULT, 2010, p. 66).

É possível dizer, também, que essa dramática que aí aparece como elemento privilegiado dessa relação do sujeito do discurso com o outro parece ser um dos principais aspectos dessa relação, porque ela supóe uma relação não somente com outrem, restringindo-se a um jogo de poder que compreende o consciente e o que pode ser evidenciado linguisticamente, como também com o outro que lhe escapa à consciência e ao discurso, produzindo uma afecção naquele outrem, incomodam-no e instigam-no a pensar nesse outro de si emergente nessa relação. Esse outro de si incomoda e traumatiza a outrem, dando o que pensar aos partícipes dessas relaçóes e, sobretudo, o que se pensar em relação a si próprio. Ele produz um pathos do qual os sujeitos nessa relaçáo procuram se livrar, vivendo a fragilidade de suas existências e as incertezas de seus destinos. Decorrendo de acontecimentos (grandes ou pequenos, históricos ou singulares), aos quais os sujeitos não podem significar imediatamente, esse outro os atravessam e os fazem experimentar em si mesmo a ambígua sensação de que não estaria preparado para tal (o "por que estou passando por isso?") e, ao mesmo tempo, de que teria a 
força, a virtude da coragem e a estatura moral para enfrentálos (a confiança de que, mesmo em risco, “devo enfrentá-lo”). Essa experimentaçáo de si, decorrente do acontecimento, e aquela incerteza proveniente das vicissitudes da vida poderiam suscitar nos sujeitos que as experienciam um sentimento tal que, salvo pelo fato de decorrerem de uma existência em que a arte os auxilia a se dar forma, faz de si mesmos seus elementos e artistas, em que o devir comporta uma dramática apresentada como o móvel de sua própria transformação e, ao mesmo tempo, como o que irrompe a ordem do discurso, não se deixando apreender pela pragmática na linguagem.

Se essa pragmática está presente na esfera pública e rege as relaçôes políticas atuais, ela não deixa de conduzir também a educaçáo e, particularmente, a escola. Isso porque deu nova configuraçáo à pedagogia, na contemporaneidade. Ao almejar cada vez mais uma alta eficiência no processo de aquisição de habilidades e de constituição de competências aos sujeitos aos quais se destina, a pedagogia se apoiou integralmente na ciência, na técnica e numa pragmática que se restringe a transmitir informaçóes com as quais o sujeito a quem se destina pode lidar e se habilitando com elas conforme a sua cognição para o exercício de conjuntos de funçóes sociais específicas. $\mathrm{O}$ ensino pensado em termos pedagógicos se restringiu a essa transmissão de informaçóes eficientes e, porque úteis ao desempenho de uma função, supostamente verdadeiras, desconsiderando os seus efeitos passionais, acontecimentais e experienciais para a transformação do ser, assim como tudo que ultrapasse uma racionalidade instrumental, um pensar único e um sujeito idêntico a si mesmo.

Ao focalizar na pragmática de si uma dramática do discurso que aborda os fatos que ficaram de fora da significação, da lógica e da ordem discursiva existente, o filósofo francês procura contrastá-la à atual pragmática da linguagem, considerando ser necessário não apenas abrange-los por uma análise mais aguda, como também compreender seus efeitos sobre o seu enunciador, o que implicaria a assunção de uma

\section{政}


atitude ética em relação à verdade e a assunção de uma posição política. É nesse sentido, se seguirmos a interpretação de Gros (2002), que Foucault promove um descentramento a partir do contraste da subjetivação antiga com a subjetividade moderna, a fim de fazer se repensar a política, especificamente, em um de seus aspectos - o dos "assujeitamentos identitários" - criando a necessidade de se pensar algo novo para ela, por um lado, tirando-lhe de sua naturalização, e, por outro, concebendo-a em sua historicidade, ainda que para tal fosse necessário retomar a antiguidade. Estrategicamente, assim, parece optar por escolher essa tradição da filosofia como modo de vida em razão do estranhamento que ela provoca em nós, seus leitores, no presente. $\mathrm{O}$ mesmo se pode inferir em relação à indicaçáo que faz ao focar a psicagogía em relação à pedagogia, porém, no que se refere ao ensino em geral e ao ensino de Filosofia em particular, temas com os quais não se ocupou, pode-se dizer pouco a partir de suas obras, mas a partir do que entendeu por essa pragmática da linguagem, que os opera, é possível considerar que o seu contraste com uma análise da dramática discursiva, no presente, seria, mais que oportuno, necessário.

$\mathrm{Na}$ medida em que aquela pragmática se restringiu, em sua aplicação ao ensino, nos últimos anos a excluir e a interditar essa dramática, juntamente com os acontecimentos que o atravessam, ela se restringiu ao planejado e ao programado pedagogicamente para dotar seus destinatários de saberes e, mais recentemente, informaçóes que não possuiriam originalmente, recorrendo ao gênero analítico da ciência e ao razão cognoscente da certeza epistêmica, sem se ater aos demais gêneros discursivos e à verdade ligada ao ethos. Diante desse quadro, o cuidado requerido pela psicagogía e a mobilização de outros gêneros do discurso para operar também nesse sentido da dramática potencializaria um estranhamento do sujeito que o enuncia, ao atentar a e acolher os acontecimentos que irrompem na pragmática do ensino e que o mobilizam para uma prática de si em que, eventualmente, antes do que v. 20 , n. 2 , p. $15-44$, transformar aos seus destinatários transforma a si. Mas é dessa 
prática de si que se extrai o material, as experiências e os pensamentos a partir dos quais se faz as eventuais escolhas de gêneros de discurso a serem utilizados para convidar outrem às práticas de si e de liberdade. Nesse caso, não se trata de uma transmissão pedagógica, tampouco de uma comunicação de informaçôes rápidas e ágeis para a aquisição de habilidades e o desenvolvimento de competências, mas da utilização de discursos que façam gerar atitudes que, muitas vezes, escapam ao que o sujeito que o enuncia pretende, planeja e programa para seus destinatários, já que dependem destes últimos, das condiçôes e, principalmente, das disposiçóes que se encontram.

\section{CONSIDERAÇÓES FINAIS}

Iluminar essa dimensão sombria da pragmática e do acontecimento, contemporaneamente, náo significa postular que a educação escolar deveria se restringir, inversamente ao que faz no presente, a colocar em circulação discursos exclusivamente que provoquem essas disposiçóes e sejam capazes de formar atitudes, para reaver o seu sentido formativo. Isso porque, anacronicamente, isso seria sugerir que a educação praticada nessa instituição abandonasse as verdades às quais os seus destinatários também necessitam, mediante o aprendizado de saberes especializado e de técnicas, assim como da subordinaçáo a tecnologias do eu, as quais esses sujeitos se equipam para enfrentar o mundo.

Ainda que não os proveja de atitudes diante da vida e ampliem o exercício do biopoder, esses conhecimentos transmitidos aos sujeitos e o domínio de si deles exigidos, tomam parte nos mecanismos pedagógicos e na arte de governo exercida historicamente por essa instituição, juntamente com a função disciplinar e normativa assumida desde a modernidade. Nesse sentido, essa transmissão e governo de si são pressupostos ou condiçôes das práticas que compreendem o ensino ou, mesmo, a educaçáo moral desenvolvida na escola. Ao mesmo tempo, elas são possibilidade de que, nas relaçóes de poder entretecidas, se produza também no sujeito algo que

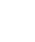


ultrapasse seu assujeitamento e que o instigue à criação de outros modos de subjetivação. Afinal, a escola ocupa apenas parte do tempo dos indivíduos e, sobretudo, uma etapa de suas vidas, uma vez que eles transitam por outras instituiçóes sociais que ampliam a sua equipagem e, nesse trânsito, se se dispuserem, auxiliam a formar atitudes para enfrentar as vicissitudes e os acontecimentos com que se deparam. Assim, os indivíduos aprendem a se conduzir de modo a ultrapassar a disciplina e as normas impostas pela instituição, na melhor das hipóteses, tornando-se capazes de fazer escolhas que possibilitem um viver mais livre e se posicionar nos jogos de poder que comandam o mundo.

A educação escolar, nessa perspectiva, deveria ser menos ambiciosa em relaçáo aos seus objetivos, do mesmo modo que as práticas que a compreendem na escola, ao reformular os discursos pedagógicos em circulação que prometem além do possível. Isso porque as práticas que compreendem a educação escolar são responsáveis por dotar os indivíduos a quem se destinam de certa equipagem para jogar o jogo, com suas regras, normas e regulamentos, que os implicam com as relaçóes de poder nas quais se encontram, porém, podem também instiga-los a se disporem a enfrentar as vicissitudes da vida e os acontecimentos que irrompem no mundo. Quando bem executada, essa tarefa não é desprezível, e é extremamente importante para que as necessidades sejam supridas e a liberdade possa emergir náo das ideias, mas da açáo dos indivíduos que, diante dos jogos de poder e de governo aos quais estão submetidos, possam exigir náo querer serem governados mais de determinada forma, como sugerido pela perspectiva da ontologia crítica foucaultiana.

Os indivíduos poderiam assumir, deliberadamente, uma atitude crítica relativa ao seu presente e se voltarem sobre si a fim de encontrar, mais do que conhecimento, disposição e coragem para agir no sentido de criar condiçóes mais livres para a sua existência e, no mundo, modificar as relaçóes com outrem. Mas tal mudança só ocorreria se eles 
próprios se ocuparem de sua transformação, nela trabalharem, utilizando o que possuem de recurso e de equipagem pessoal, que poderm ser oferecidos por outrem, sejam aqueles que têm alguma responsabilidade pela sua educaçáo e, no caso da escola, de seus professores, seja por um outro, relacionado àquelas relaçóes ou às que estabelece com o mundo. Assim, se, por um lado, estariam subordinados a uma relação de poder em que a governamentalidade e o cuidado se entretecem e atuam concomitantemente, por outro, poderiam buscar, nas suas relaçóes com as coisas e com o mundo, se libertar daquilo que nela os aprisionam, em vistas a produzir uma existência e práticas de subjetivaçóes mais livres, mesmo em instituiçóes como a escola.

Restaria saber se, para isso, esses indivíduos teriam disposiçáo e coragem para atuarem não somente como elementos, mas como atores dessa instituição e do mundo ao qual pertence. Uma disposição subjetiva e uma atitude que, de um lado, supóe a assunção de certo risco diante da vida, enquanto que, de outro, exige certa abertura para a sua própria (trans)formação. Este espaço subjetivo, essa abertura a experimentação de si, parece ser, dessa forma, um lugar afortunado para a arte de viver no âmbito escolar e, neste âmbito, a vida como obra de arte pode provocar certo deslocamento no debate pedagógico atual, sendo essa a meu ver a principal contribuição das obras e últimos cursos de Foucault para os estudos recentes em Filosofia da Educação sobre o tema da formação humana.

\section{REFERÊNCIAS}

CASTRO, E. El vocabulario de Michel Foucault: un recorrido alfabético por sus temas, conceptos y autores. Buenos Aires: Universidad Nacional de Quilmes, 2004.

DELEUZE, G. Conversaçôes. 3. ed. Rio de Janeiro: 34, 2000.

FOUCAULT, M. O que é o iluminismo. In: ESCOBAR, C.H. (org.). Michel Foucault (1926-1984): o Dossier - últimas entrevistas. Rio de Janeiro: Livraria Taurus Editora, 1984. p. 102-113.$$
\text { . }
$$ 
O que é crítica? (Crítica e Aufklärung). Cadernos da FFC (Marília): Foucault - História e os destinos do pensamento. 9(1), 169-189, 2000.

. A ética do cuidado de si como prática da liberdade. In: FOUCAULT, M. Ditos \& Escritos: Ética, sexualidade e política. Vol. V. São Paulo: Forense Universitária, 2004a, p. 264-287.

. Hermenêutica do Sujeito. São Paulo: Martins Fontes, $2004 \mathrm{~b}$.

- El pensamiento del afuera. Valencia: Pre-textos, 2004c.

. O retorno da moral. In: FOUCAULT, M. Ditos \& Escritos: Ética, sexualidade e política. Vol. V. São Paulo: Forense Universitária, 2004d, p. 253-263. 2008.

. Tecnologías del yo: y otros textos afines. Barcelona: Paidós,

. Le courage de la verité: le gouvernement de sui y des autres II. Paris: Gallimard/Seuil, 2009.

2010.

. O Governo de si e dos outros. Sáo Paulo: Martins Fontes,

GROS, F. Sujet moral et soi éthique chez Foucault. Archives de Philosophie. 2002/2 Tome 65, p. 229-237. [acessado em 18/05/2012, em http://www.cairn.info/revue-archives-de-philosophie-2002-2page-229.htm]

GROS, F; LÉVY, C. (dir.) Foucault y la Filosofía Antigua. Buenos Aires: Ediciones Nueva Visíon, 2004.

HADOT, P. Exercises Spirituels et Philosophia Antique. Paris: Albin Michel, 2002 [ Nouvelle editión revue et augmentée].

HERMANN, N. Ética: a aprendizagem da arte de viver. Revista Educação e Sociedade, Campinas, Cedes, v. 29, n. 102, p. 15-32, 2008.

JAY, M. Cantos de experiencia: variaciones modernas sobre un tema universal. Buenos Aires: Paidós, 2009.

VILELA, E. Silêncios tangiveis: corpo, resistência e testemunho nos espaços contemporâneos de abandono. Porto: Afrontamentos, 2010. 